\title{
Changes in Blood Cell Morphology and Number of Red Spotted Grouper, Epinephelus akaara in Response to Thermal Stress
}

\author{
Md Mofizur Rahman ${ }^{1,2}$, Hyung Bae Kim³, and Hea Ja Baek ${ }^{1}$ \\ ${ }^{1}$ Dept. of Marine Biology, Pukyong National University, Busan 48513, Korea \\ ${ }^{2}$ Dept. of Fisheries and Marine Science, Noakhali Science and Technology University, Noakhali 3814, Bangladesh \\ ${ }^{3}$ Dept. of Marine Bio-Resources, Gangwon Provincial College, Gangnung 25425, Korea
}

\begin{abstract}
Rising of water temperature due to global warming is a great concern to aquaculturists and fishery biologists. Hence, the present study aimed to investigate the effects of high water temperature on juvenile red spotted grouper, Epinephelus akaara based on the evaluation of stress responses in blood. E. akaara juveniles were exposed to different thermal conditions $\left(25^{\circ} \mathrm{C}, 28^{\circ} \mathrm{C}, 31^{\circ} \mathrm{C}\right.$, and $\left.34^{\circ} \mathrm{C}\right)$ for 6 weeks following 2 weeks of acclimation at $25^{\circ} \mathrm{C}$. Blood cell morphology and number were examined at three sampling points (2, 7, and 42 days) from a total of 180 fish. Major erythrocytic cellular abnormalities (ECA) observed in blood smears of thermally stressed groups $\left(31^{\circ} \mathrm{C}\right.$ and $\left.34^{\circ} \mathrm{C}\right)$ after 6 weeks were echinocytes, teardrop-like cells, swollen cells and vacuolated cells. Both red and white blood cell number (RBC and WBC) were significantly $(p<0.05)$ elevated in $31^{\circ} \mathrm{C}$ and $34^{\circ} \mathrm{C}$ group after 6 weeks thermal exposure. Differential leucocytes number showed significant increases in neutrophil $(\mathrm{N})$ and decreases in lymphocytes $(\mathrm{L})$ in the highest temperature $\left(34^{\circ} \mathrm{C}\right)$. Different N:L ratio was observed at different thermal conditions which can be used as a reliable alternative to measure stress response. Taken together, these results suggest that higher temperature $\left(31^{\circ} \mathrm{C}\right.$ and $\left.34^{\circ} \mathrm{C}\right)$ can interfere the immune system of red spotted grouper by altering the blood cell morphology and number.
\end{abstract}

Key words : Epinephelus akaara, Temperature, Stress response, Blood cell morphology, Blood cell number

\section{INTRODUCTION}

Water temperature is one of the vital environmental variables that influence the biology of fishes (Dunham et al., 2003). The rise in water temperature due to global warming is a great concern of aquaculturists and fishery biologists. The fluctuations in water temperature may significantly provoke the normal physiological processes, growth and survival of teleost fish, thereby declining the fish abundance (Portner \& Peck, 2010). The normal water temperature range in the tropics to which fish are well adapted is $25^{\circ} \mathrm{C}-35^{\circ} \mathrm{C}$ (Howerton, 2001). Although the thermal preference level varies from species to species, however, temperature can rise to a point that could be harmful for fish growth and impairment of physiological processes (Fu et al., 2018).

Blood is the most efficient indicator related to immune response that express endogenous or exogenous changes in fish (Bowden et al., 2007; Simide et al., 2016). It is easy to collect fish blood and the parameters associated with blood can provide sufficient information about the immune system of fish to environmental changes that affect homeostasis

Manuscript received April 13, 2019, Received in revised form May 2, 2019, Accepted May 18, 2019

${ }^{\dagger}$ Corresponding Author : Hea Ja Baek, Dept. of Marine Biology, Pukyong National University, Busan 48513, Korea. Tel: +82-51-629-5924, E-mail: hjbaek@pknu.ac.kr

This is an Open Access article distributed under the terms of the Creative Commons Attribution Non-Commercial License (http:// creative-commons.org/licenses/by-nc/3.0) which permits unrestricted non-commercial use, distribution, and reproduction in any medium, provided the original work is properly cited. 
(Cazenave et al., 2005; Elahee \& Bhagwant, 2007). The morphology and number of erythrocytes vary with ambient temperature (Ytrestoyl et al., 2001). It has been reported that various erythrocytic alterations due to thermal stress are effective indicator of cytotoxicity (Shahjahan et al., 2018; Islam et al., 2019). Cell shrinkage and membrane blebbing are signs for apoptotic cells (Talapatra \& Banerjee, 2007). Though a number of studies have been conducted for better understanding of physiological thermal stress responses of aquatic organisms (Ahmad et al., 2011; Cheng et al., 2013), the high temperature effects on blood profiles of red spotted grouper Epinephelus akaara, are not well studied. Analysis of blood profiles in response to thermal exposure is required to get a rapid feedback about the immune response of the stressed fish and thus will help to develop advance management strategies for the improvement of fish habitat in consideration of rising sea water temperature.

Groupers are warm water fish that spawn and grow best at $24^{\circ} \mathrm{C}$ to $30^{\circ} \mathrm{C}$; most of them prefer a thermal range of $15^{\circ} \mathrm{C}$ to $35^{\circ} \mathrm{C}$ (Tucker, 1999). Among the groupers, the red spotted grouper, E. akaara is a sub-tropical species that occurs in southern Japan, Korea, Hong Kong, Taiwan, and southern China (Kim et al., 2005). It is a commercially important species in southeastern Asia due to its high market value (Morris et al., 2000). However, overexploitation, habitat degradation, and global climate change effects have reduced the landings of this species, making natural stocks vulnerable (Tupper \& Sheriff, 2008). The International Union for the Conservation of Nature (IUCN) has listed $E$. akaara as an endangered species (Sadovy et al., 2018). Therefore, appropriate management and conservation measures are necessary to protect this endangered species.

Nowadays, it has been observed that the seawater temperature exceeds beyond the normal tolerance range of fish $\left(24^{\circ} \mathrm{C}\right.$ to $\left.30^{\circ} \mathrm{C}\right)$ (Noyes et al., 2009). Considering this, we have investigated the thermal effects on red spotted grouper in our previous studies and shown that high thermal exposure $\left(>30^{\circ} \mathrm{C}\right)$ can alter the hematological and biochemical parameters [Cho et al., 2015; Lee \& Baek, 2018; Rahman et al., 2019 (unpublished data)]. Nonetheless, there is no published information about the blood characteristics of red spotted grouper (E. akaara) at higher thermal exposure. Therefore, in the present study, we intended to know how high water temperature affects the blood cell morphology and number in red spotted grouper after rearing at longer periods.

\section{MATERIALS AND METHODS}

\section{Experimental animals and maintenance}

Healthy and active juveniles of E. akaara were obtained from the Marine Science Institute, Jeju National University, Korea. The mean total length (TL) and body weight (BW) were $8.28 \pm 0.10 \mathrm{~cm}$ and $8.53 \pm 0.27 \mathrm{~g}$, respectively. Fish were acclimated in aquaria at a water temperature of $25 \pm 0.5^{\circ} \mathrm{C}$, salinity of $34 \mathrm{psu}$, dissolved oxygen levels $\geq 6.6$ $\mathrm{mg} / \mathrm{L}, \mathrm{pH}$ of 7.8 , and a 12L:12D photoperiod for 2 weeks before the experiment. Fish were fed commercial feed (Otohime Hirame; Marubeni Nisshin Feed Co., Ltd., Tokyo, Japan) twice daily at 09:00 and 18:00 h until satiation, until $24 \mathrm{~h}$ before the experimental trial. Uneaten food was removed after 30 minutes of feeding to control water quality.

\section{Experimental design and thermal exposure}

A total of 180 juvenile red spotted grouper were selected and randomly distributed into 12 rectangular glass tanks $(75 \times 45 \times 45 \mathrm{~cm}, \mathrm{~W} \times \mathrm{L} \times \mathrm{H})$ containing 15 fish per tank. Each tank was filled with $120 \mathrm{~L}$ seawater and equipped with a recirculating filtration system. The fishes were exposed to four temperature conditions $\left(25^{\circ} \mathrm{C}\right.$ as control, $28^{\circ} \mathrm{C}, 31^{\circ} \mathrm{C}$, and $34^{\circ} \mathrm{C}$ ), each with three replications for 6 weeks. Temperature was gradually increased $\left(\Delta 1^{\circ} \mathrm{C} / \mathrm{h}\right)$ using a thermostat (OKE-6422H; OKE, Busan, Korea) to reach the target temperature conditions $\left(25^{\circ} \mathrm{C}, 28^{\circ} \mathrm{C}, 31^{\circ} \mathrm{C}\right.$, and 
$34^{\circ} \mathrm{C}$ ). Each experimental aquarium was maintained at a constant temperature $\pm 0.5^{\circ} \mathrm{C}$ with supplemental aeration and skimming. Survival of the experimental fish was monitored over the entire rearing period. Water temperature, $\mathrm{pH}$, salinity, and dissolved oxygen were checked daily using a water quality meter (HI9829; Hanna Instrumentals, Woonsocket, RI, USA) and total ammonium levels were measured every 2 days using an $\mathrm{NH}_{3} / \mathrm{NH}_{4}{ }^{+}$test kit (Tetra $\mathrm{GmbH}$, Melle, Germany). Approximately $10 \%$ of the water was replaced daily with filtered clean seawater as feces and debris were siphoned from the tank. Fish maintenance, handling, and sampling were conducted according to the guidelines of the Animal Ethics Committee of Pukyong National University (PKNU) (Regulation No. 554).

\section{Blood sampling and analysis}

Fish were sampled at 2 days, 1 week, and 6 weeks after the thermal exposure starting point. At each sampling point, five fishes were sampled from each aquaria (15 fishes from each temperature group; $\mathrm{n}=15$ ). Fish were randomly captured and lightly anaesthetized with $300 \mathrm{ppm}$ 2-phenoxyethanol (Sigma Aldrich, St. Louis, MO, USA). Blood was collected from the caudal vein using heparinized capillary tubes, labeled, and stored in $1.5 \mathrm{~mL}$ centrifuge tubes for analysis of blood indices. Whole blood withdrawal process was done less than $1 \mathrm{~min}$ per fish to avoid handling stress.

The red and white blood cells ( $\mathrm{RBC}$ and $\mathrm{WBC}$ ) were counted under a light microscope (BX-50; Olympus, Tokyo, Japan) using an improved Neubauer Hemocytometer (Blaxhall \& Daisley, 1973). Blood was smeared on clean microscopic slides immediately after collection, air-dried for $10 \mathrm{~min}$, fixed in methanol for $10 \mathrm{~min}$, stained with Wright-Giemsa solution, rinsed with distilled water, airdried and mounted with malinol. Three blood smeared slides were prepared from of each fish and 100 cells were scored from each slide. Frequencies of differential leucocytes were recorded from blood smears according to the methodology proposed by Davis et al. (2008).

Erythrocytic cellular abnormalities (ECA) and differential leucocytes, such as monocytes (Mo), neutrophil (N), lymphocytes (L), eosinophil (Eo), and basophil (Ba) were examined from the blood smear of fishes reared in different thermal conditions under a light microscope (BX50; Olympus, Tokyo, Japan; $\times 600$ magnification). The ECA were dissimilar from the normal erythrocyte cell (oval-shaped with a condensed nucleus).

\section{Statistical analysis}

All data are presented as means \pm SEM. One-way analysis of variance (ANOVA) followed by Duncan's multiple range test was used to assess the significant differences among the different temperature groups. Statistical significance was set at $p<0.05$. Data analysis were performed using SPSS statistics software (ver. 21.0; IBM Corp., Armonk, NY, USA).

\section{RESULTS}

\section{Changes in blood cell morphology}

Thermal exposure induced various ECAs in $31^{\circ} \mathrm{C}$ and $34^{\circ} \mathrm{C}$ groups on day 2 (Fig. 1C, D) compared to those in the $25^{\circ} \mathrm{C}$ and $28^{\circ} \mathrm{C}$ groups (Fig. $1 \mathrm{~A}, \mathrm{~B}$ ). After 1 week, $34^{\circ} \mathrm{C}$ induced more erythrocytic damage showing echinocytes (Ec) and swelled blood cells (Sc) (Fig. 2B), and $31^{\circ} \mathrm{C}$ group showed normal erythrocyte structure (Er) with oval shaped (Oc) (Fig. 2A). However, $25^{\circ} \mathrm{C}$ and $28^{\circ} \mathrm{C}$ group did not show any erythrocytic abnormalities after 1 and 6 weeks of heat exposure (Figure not shown). After 6 weeks, massive alteration in erythrocytes continued in $34^{\circ} \mathrm{C}$ group (Fig. 2D) and a sign of erythrocytic (Er) stress was also recorded in $31^{\circ} \mathrm{C}$ group (Fig. 2C). The other major signs of RBCs alterations included tear drop like cells $(\mathrm{Tr})$, eliptocyte cells (El), round shaped cells (Rc), microcytic RBCs (Mc), bite cell (Bi), hemolyzed RBC cells $(\mathrm{Hc})$, and vacuolated cells $(\mathrm{Va})$. 


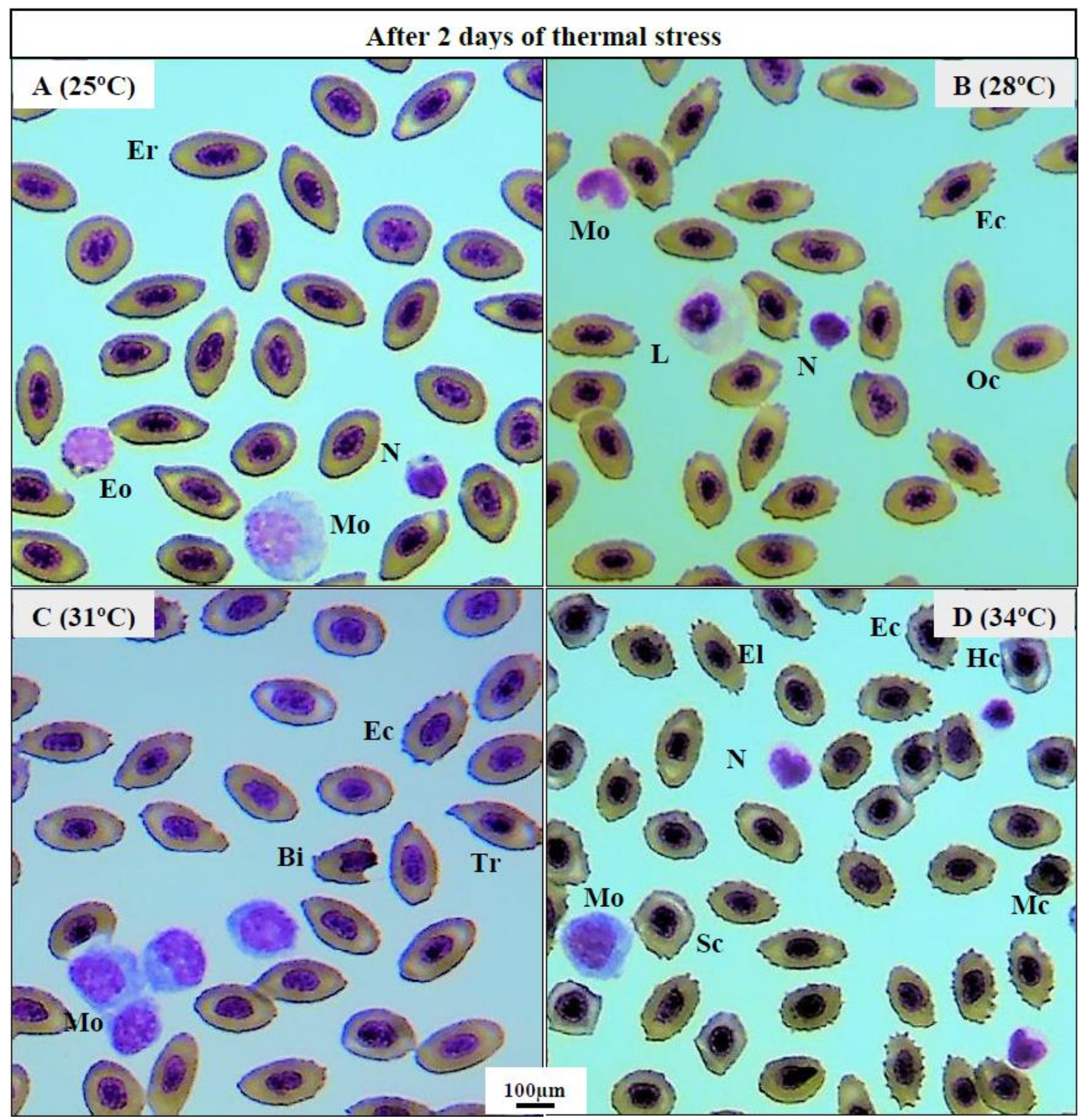

Fig. 1. (A)-(D) Blood smear of red spotted grouper Epinephelus akaara after 2 days of thermal exposure at different level $\left(25^{\circ} \mathrm{C}, 28^{\circ} \mathrm{C}, 31^{\circ} \mathrm{C}\right.$, and $\left.34^{\circ} \mathrm{C}\right)$ illustrating the various types of cell including normal erythrocyte (Er) with oval shaped cells $(\mathrm{Oc})$; different types of leucocytes including monocytes (Mo), lymphocyte $(\mathrm{L})$, neutrophil (N), eosinophil (Eo) and various ECAs including echinocyte (Ec), teardrop-like cells (Tr), bite cell (Bi), eliptocyte (EI), swelled cells (Sc), microcytic RBC (Mc), hemolyzed cells (Hc). Wright-Giemsa stain; Scale bars=100 $\mu \mathrm{m}$.

\section{Changes in red and white blood cell number}

Thermal exposure significantly elevated the RBCs at $34^{\circ} \mathrm{C}$ on day 2 , whereas WBCs increased at $31^{\circ} \mathrm{C}$ and $34^{\circ} \mathrm{C}$ group. After 1 week, both RBC and WBC number were significantly elevated at $34^{\circ} \mathrm{C}$ compared to those in the $25^{\circ} \mathrm{C}, 28^{\circ} \mathrm{C}$, and $31^{\circ} \mathrm{C}$ groups. However, after 6 weeks, thermal stress significantly raised both $\mathrm{RBC}$ and $\mathrm{WBC}$ number in $31^{\circ} \mathrm{C}$ and $34^{\circ} \mathrm{C}$ group (Table 1 ). 


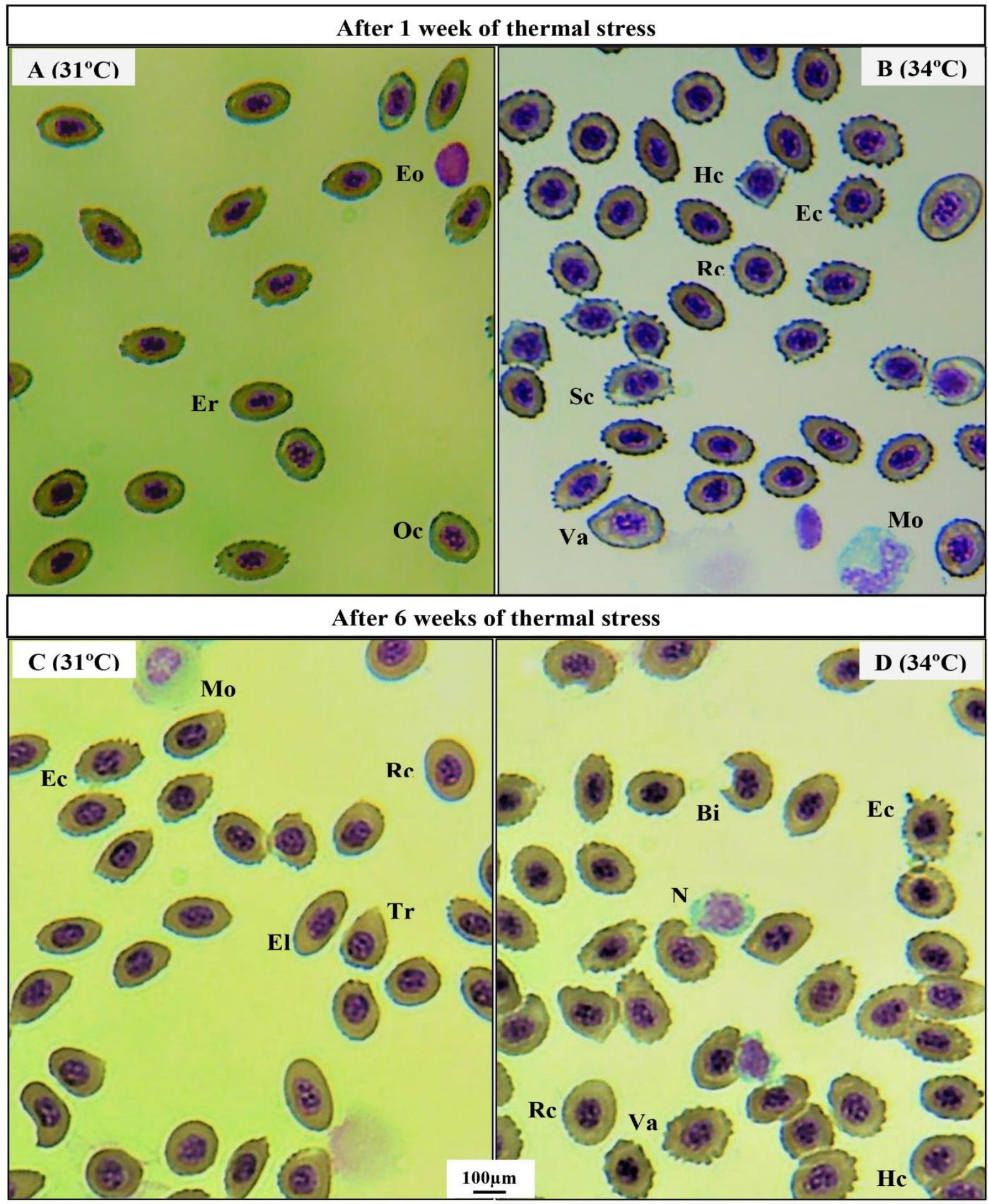

Fig. 2. (A)-(D) Blood smear of red spotted grouper Epinephelus akaara after 1 week and 6 weeks of thermal exposure at $31^{\circ} \mathrm{C}$ and $34^{\circ} \mathrm{C}$ illustrating the different cell types including normal erythrocyte (Er) with oval shaped cells (Oc); different types of leucocytes including monocytes (Mo), neutrophil (N), eosinophil (Eo) and various ECAs including echinocyte (Ec), round shaped cells $(\mathrm{Rc})$, teardrop-like cells (Tr), bite cell (Bi), eliptocyte (EI), swelled cells (Sc), vacuolated cells (Va), hemolyzed cells (Hc). Wright-Giemsa stain; Scale bars $=100 \mu \mathrm{m}$. 
Table 1. Changes of red and white blood cell counts (RBC and WBC) of juvenile red spotted grouper after thermal exposure of 2 days, 1 week and 6 weeks at different water temperature $\left(25^{\circ} \mathrm{C}, 28^{\circ} \mathrm{C}, 31^{\circ} \mathrm{C}\right.$, and $\left.34^{\circ} \mathrm{C}\right)$

\begin{tabular}{|c|c|c|c|c|}
\hline \multirow{2}{*}{ Parameters } & \multirow{2}{*}{ Temperature } & \multicolumn{3}{|c|}{ Thermal exposure period } \\
\hline & & 2 days & 1 week & 6 weeks \\
\hline \multirow{4}{*}{$\mathrm{RBC}\left(\times 10^{6} / \mathrm{mm}^{3}\right)$} & $25^{\circ} \mathrm{C}$ & $3.99 \pm 0.15^{\mathrm{b}}$ & $3.89 \pm 0.05^{\mathrm{bc}}$ & $3.68 \pm 0.04^{\mathrm{c}}$ \\
\hline & $28^{\circ} \mathrm{C}$ & $3.92 \pm 0.09^{\mathrm{b}}$ & $3.75 \pm 0.16^{c}$ & $3.61 \pm 0.07^{\mathrm{c}}$ \\
\hline & $31^{\circ} \mathrm{C}$ & $4.06 \pm 0.19^{\mathrm{b}}$ & $4.16 \pm 0.09^{b}$ & $4.53 \pm 0.19^{\mathrm{b}}$ \\
\hline & $34^{\circ} \mathrm{C}$ & $5.18 \pm 0.24^{\mathrm{a}}$ & $5.14 \pm 0.04^{\mathrm{a}}$ & $5.30 \pm 0.09^{\mathrm{a}}$ \\
\hline \multirow{4}{*}{$\mathrm{WBC}\left(\times 10^{3} / \mathrm{mm}^{3}\right)$} & $25^{\circ} \mathrm{C}$ & $9.81 \pm 0.49^{\mathrm{c}}$ & $9.19 \pm 0.43^{\mathrm{c}}$ & $8.67 \pm 0.30^{\mathrm{b}}$ \\
\hline & $28^{\circ} \mathrm{C}$ & $9.52 \pm 0.14^{\mathrm{c}}$ & $8.83 \pm 0.18^{c}$ & $8.18 \pm 0.63^{\mathrm{b}}$ \\
\hline & $31^{\circ} \mathrm{C}$ & $12.31 \pm 0.02^{\mathrm{b}}$ & $11.63 \pm 0.27^{\mathrm{b}}$ & $13.03 \pm 0.36^{\mathrm{a}}$ \\
\hline & $34^{\circ} \mathrm{C}$ & $13.45 \pm 0.21^{\mathrm{a}}$ & $14.24 \pm 0.08^{\mathrm{a}}$ & $13.58 \pm 0.25^{\mathrm{a}}$ \\
\hline
\end{tabular}

Values are mean \pm SEM of three replicates ( $\mathrm{n}=15 ; 5$ fish per tank).

Different lowercase letters in each column indicate the significant difference between groups at equivalent times (ANOVA, Duncan's multiple range test; $p<0.05$ ).

\section{Changes in differential leucocyte number}

Monocyte and neutrophil number were significantly higher in $31^{\circ} \mathrm{C}$ and $34^{\circ} \mathrm{C}$ throughout the thermal exposure period (Fig. 3A, C), whereas the number of lymphocytes were decreased in $31^{\circ} \mathrm{C}$ and $34^{\circ} \mathrm{C}$ (Fig. 3B). As consequences, the $\mathrm{N}: \mathrm{L}$ ratio was significantly different among the thermal exposure groups (Fig. 3F). However, no change was recorded in eosinophil and basophil number in any group after 6 weeks of thermal exposure (Fig. 3D, E).

\section{DISCUSSION}

Temperature beyond the tolerance range for a particular species adversely affects its immune capacity, hence increase the susceptibility to diseases that have suppressive effects on growth and reproduction (Cnaani, 2006). In this study, red spotted grouper juveniles were overwhelmed by thermal stress at higher exposure $\left(31^{\circ} \mathrm{C}\right.$ and $\left.34^{\circ} \mathrm{C}\right)$, which affects their blood cell morphology and number. Fishes of $34^{\circ} \mathrm{C}$ were severely affected after 6 weeks of thermal exposure and showed less appetite for feed, gulping for air and irregular body movement. The common carp (Cyprinus carpio var. communis) exhibited similar behavior when exposed to $32^{\circ} \mathrm{C}$ for a period of one month (Ahmad et al., 2011).

In the present study, several ECA like echinocytes, teardrop-like cells, swollen cells and vacuolated cells were observed in blood smears of thermally exposed fish $\left(31^{\circ} \mathrm{C}\right.$ and $\left.34^{\circ} \mathrm{C}\right)$ in comparison with other groups $\left(25^{\circ} \mathrm{C}\right.$ and $28^{\circ} \mathrm{C}$ ). These results clearly indicate the sign of stress which can lead to an anemic condition of experimental animals at higher thermal exposure $\left(34^{\circ} \mathrm{C}\right)$. Similar erythrocytic alterations were reported in striped catfish, Pangasianodon hypophthalmus when treated with higher temperature $\left(36^{\circ} \mathrm{C}\right)$ for 7 and 28 days (Islam et al., 2019). The observed vacuoles in erythrocytes may be resulted from unequal distribution of hemoglobin (Mekkawy et al., 2011). The swelled blood cells were recorded as signs of necrosis (Ateeq et al., 2002). Echinocytes is type of erythrocytic abnormality that formed due to interruption in 

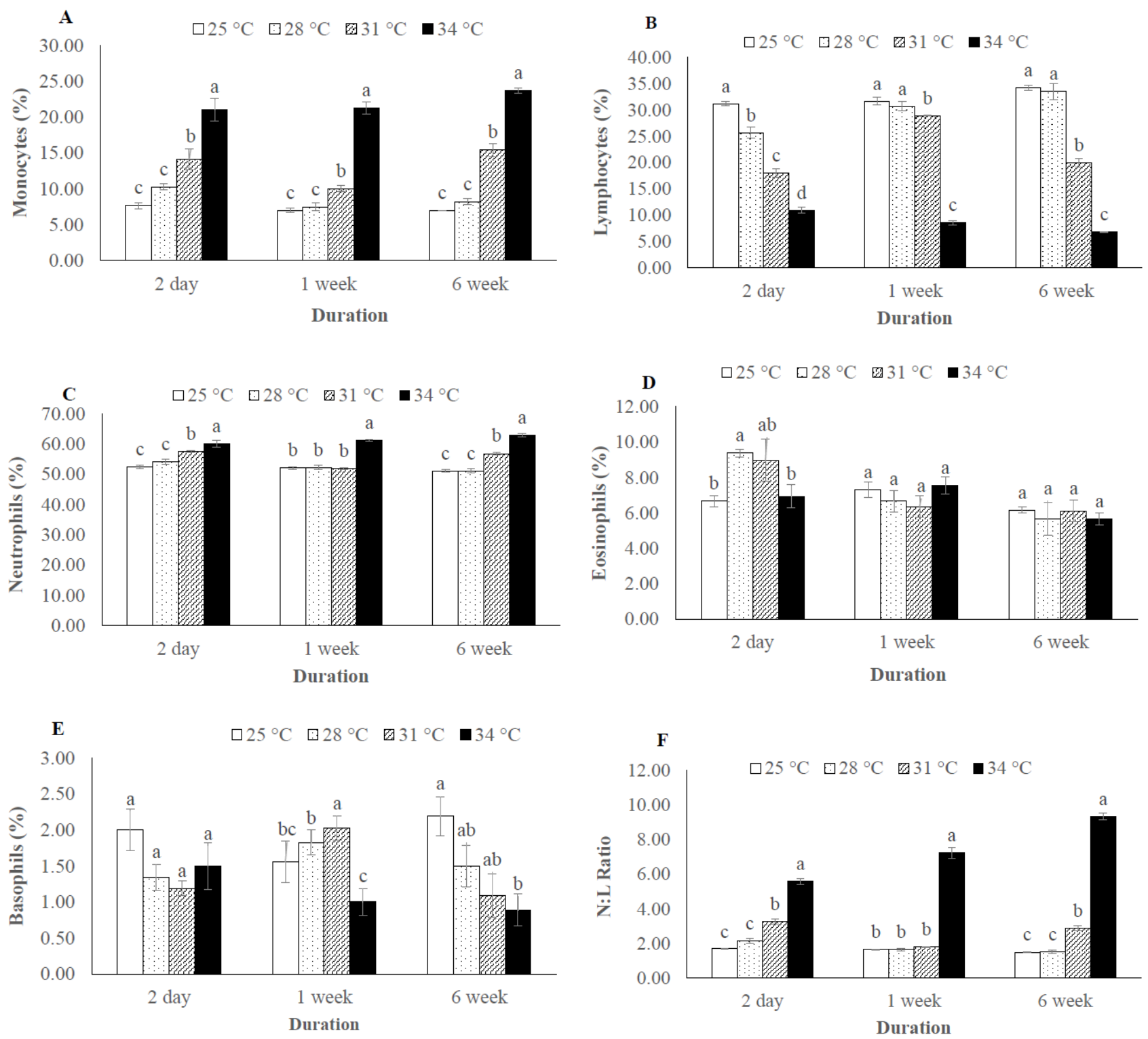

Fig. 3. (A)-(F) Differential leucocyte number (Monocytes, lymphocytes, Neutrophils, Eosinophils, Basophils, N:L ratio) of juvenile red spotted grouper after 2 days, 1 week and 6 weeks of thermal exposure at different level $\left(25^{\circ} \mathrm{C}, 28^{\circ} \mathrm{C}, 31^{\circ} \mathrm{C}\right.$, and $\left.34^{\circ} \mathrm{C}\right)$. Values are mean $\pm \mathrm{SEM}$ of three replicates ( $\mathrm{n}=15 ; 5$ fish per tank). Different lowercase letters indicate the significant difference between groups at equivalent times (ANOVA, Duncan's multiple range test; $p<0.05$ ).

lipid solubility to erythrocytes membrane which ultimately leads to apoptosis (Walia et al., 2013).

In this study, the elevated $\mathrm{RBCs}$ at $31^{\circ} \mathrm{C}$ and $34^{\circ} \mathrm{C}$ after 6 weeks thermal exposure indicates that the stressed fish tried to cope with adverse conditions by enhancing their respiratory capabilities through evaluated RBC. The higher $\mathrm{RBC}$ levels may increase the oxygen carrying capacity of blood, thus supplying oxygen to major organs in response to higher metabolic demand, which is a manifestation of stress (Ruane et al., 1999). Moreover, the observed higher WBC number at $31^{\circ} \mathrm{C}$ and $34^{\circ} \mathrm{C}$ after 6 weeks thermal exposure can be correlated with additional antibody demand that may help the fish to survive in adverse environmental condition. Similarly, RBC and WBC 
number were found to be increased with increased water temperature in striped catfish $\left(24^{\circ} \mathrm{C}\right.$ to $\left.36^{\circ} \mathrm{C}\right)$ and common carp $\left(20^{\circ} \mathrm{C}\right.$ to $\left.32^{\circ} \mathrm{C}\right)$ when reared for a period of one month (Ahmad et al., 2011; Islam et al., 2019).

In the present study, the observed increased neutrophil $(\mathrm{N})$ and decreased lymphocytes (L) among the differential leucocyte number in the higher temperature $\left(31^{\circ} \mathrm{C}\right.$ and $34^{\circ} \mathrm{C}$ ) indicates the disturbance of immune system which may lead to infectious disease to the thermally stressed fish. Similar results has been reported in P. hypophthalmus where increases neutrophils numbers (neutrophilia) and decreases lymphocyte numbers (lymphocytopenia) due to thermal stress (Shahjahan et al., 2018). Moreover, the N:L ratio can be used as an index of a secondary stress response, since the neutrophils and lymphocytes numbers are affected by stress in opposite directions (Davis et al., 2008). The present study also supports this statement as the highest $\mathrm{N}: \mathrm{L}$ was recorded in $34^{\circ} \mathrm{C}$ group. The higher $\mathrm{N}$ : L similar to our study was also recorded in juvenile dusky grouper Epinephelus marginatus (Pereira-Cardona et al., 2017) and pejerrey fingerlings Odontesthes bonariensis (Zebral et al., 2015) where stress arouse from transport and crowding, respectively.

In conclusion, the results of the present study demonstrate that thermal stress may affects the immune system of $E$. akaara at higher temperature $\left(31^{\circ} \mathrm{C}\right.$ and $\left.34^{\circ} \mathrm{C}\right)$ by altering the blood cells morphology and number. In addition, different $\mathrm{N}: \mathrm{L}$ ratio at different thermal conditions can be used as a reliable alternative to measure stress levels in juvenile E. akaara and probably in other fish species.

\section{ACKNOWLEDGEMENTS}

This research was supported by a grant (213008-05-3WT511) from Korean Ministry of Agriculture, Food and Rural Affairs (MAFRA), the Korean Ministry of Oceans and Fisheries (MOF), the Korean Rural Development Administration (RDA), and the Korea Forest Service (KFS).

\section{REFERENCES}

Ahmad SM, Shah FA, Bhat FA, Bhat JIA, Balkhi MH (2011) Thermal adaptability and disease association in common carp (Cyprinus carpio communis) acclimated to different (four) temperatures. J Therm Biol 36:492497.

Blaxhall PC, Daisley KW (1973) Routine hematological methods for use with fish blood. J Fish Biol 5:771-781.

Bowden TJ, Thompson KD, Morgan AL, Gratacap RM, Nikoskelainen S (2007) Seasonal variation and the immune response: A fish perspective. Fish Shellfish Immunol 22:695-706.

Ateeq B, Abul farah M, Niamat Ali M, Ahmad W (2002) Induction of micronuclei and erythrocyte alterations in the catfish Clarias batrachus by 2,4-dichlorophenoxyacetic acid and butachlor. Mutat Res 518:135-144.

Cazenave J, Wunderlin DA, Hued AC, de los AngelesBistoni M (2005) Haematological parameters in a neotropical fish, Corydoras paleatus (Jenyns, 1842) (Pisces, Callichthyidae), captured from pristine and polluted water. Hydrobiologia 537:25-33.

Cheng SY, Chen CS, Chen JC (2013) Salinity and temperature tolerance of brown-marbled grouper Epinephelus fuscoguttatus. Fish Physiol Biochem 39:277-286.

Cho HC, Kim JE, Kim HB, Baek HJ (2015) Effects of water temperature change on the hematological responses and plasma cortisol levels in growing of red spotted grouper, Epinephelus akaara. Dev Reprod 19: 19-24.

Cnaani A (2006) Genetic perspective on stress response and disease resistance in aquaculture. Isr J AquacultureBamidgeh 58:375-383.

Davis AK, Maney DL, Maerz JC (2008) The use of leukocyte profiles to measure stress in vertebrates: A review for ecologists. Funct Ecol 22:760-772.

Dunham J, Rieman B, Chandler G (2003) Influences of 
temperature and environmental variables on the distribution of bull trout within streams at the Southern Margin of its range. N Am J Fish Manag 23:894-904.

Elahee KB, Bhagwant S (2007) Hematological and gill histopathological parameters of three tropical fish species from a polluted lagoon on the west coast of Mauritius. Ecotoxicol Environ Saf 68:361-371.

Fu KK, Fu C, Qin YL, Bai Y, Fu SJ (2018) The thermal acclimation rate varied among physiological functions and temperature regimes in a common cyprinid fish. Aquaculture 495:393-301.

Howerton R (2001) Best management practices for Hawaiian aquaculture. Cent Trop Subtrop Aquac 148:137.

Kim IS, Choi Y, Lee CL, Lee YJ, Kim BJ, Kim JH, Kim IS, Choi Y, Lee CL, Lee YJ, Kim BY, Kim JH (2005) Illustrated Book of Korean Fishes. Kyo-Hak Publishing Co., Seoul, Korea, p 615.

Lee JW, Baek HJ (2018) Determination of optimal temperature(s) in juvenile red-spotted grouper Epinephelus akaara (Temminck \& Schlegel) based on growth performance and stress responses. Aquac Res 49:3228-3233.

Islam MA, Uddin MH, Uddin MJ, Shahjahan M (2019) Temperature changes influenced the growth performance and physiological functions of Thai pangas Pangasianodon hypophthalmus. Aquac Rep 13:100179.

Mekkawy IA, Mahmoud UM, Sayed Ael-D (2011) Effects of 4-nonylphenol on blood cells of the African catfish Clarias gariepinus (Burchell, 1822). Tissue Cell 43: 223-229.

Morris AV, Roberts CM, Hawkins JP (2000) The threatened status of groupers (Epinephelinae). Biodivers Conserv 9:919-942.

Noyes PD, McElwee MK, Miller HD, Clark BW, Van Tiem LA, Walcott KC, Erwin KN, Levin ED (2009) The toxicology of climate change: Environmental contaminants in a warming world. Environ Int 35:971-
986

Pereira-Cardona PM, Lisboa V, Barbas LAL, Robaldo RB (2017) Transport of juvenile dusky grouper Epinephelus marginatus under different packing densities: Metabolic and haematological responses. Aquac Res 48: 53565362.

Portner HO, Peck MA (2010) Climate change effects on fishes and fisheries: Towards a cause-and-effect understanding. J Fish Biol 77:1745-1779.

Rahman MM, Lee Y-N, Baek HJ (2019) Physiological and histological responses of juvenile red spotted grouper (Epinephelus akaara) to thermal stress. Manuscript submitted for publication.

Ruane NM, Wendelaar Bonga SE, Balm PH (1999) Differences between rainbow trout and brown trout in the regulation of the pituitary-interrenal axis and physiological performance during confinement. Gen Comp Endocrinol 115:210-219.

Sadovy Y, Liu M, Amorim P, Choat JH, Law C, Ma K, Myers R, Rhodes K, Samoilys M, Suharti S, To A (2018) Epinephelus akaara. The IUCN Red List of Threatened Species. T43974A100459934. https://doi. org/10.2305/IUCN.UK.2018-2.RLTS.T43974A1004599 34.en. [cited 07 Jun 2019]

Shahjahan M, Uddin MH, Bain V, Haque MM (2018) Increased water temperature altered hemato-biochemical parameters and structure of peripheral erythrocytes in striped catfish Pangasianodon hypophthalmus. Fish Physiol Biochem 44:1309-1318.

Simide R, Richard S, Prevot-D'Alvise N, Miard T, Gaillard S (2016) Assessment of the accuracy of physiological blood indicators for the evaluation of stress, health status and welfare in Siberian sturgeon (Acipenser baerii) subject to chronic heat stress and dietary supplementation. Int Aquat Res 8:121-135.

Talapatra SN, Banerjee SK (2007) Detection of micronucleus and abnormal nucleus in erythrocytes from the gill and kidney of Labeo bata cultivated in 
sewage-fed fish farms. Food Chem Toxicol 45:210-215.

Tucker JW Jr (1999) Species Profile: Grouper Aquaculture.

Southern Regional Aquaculture Center Publication, Fort Pierce, FL, USA.

Tupper M, Sheriff N (2008) Capture-based aquaculture of groupers. In: Lovatelli A, Holthus PF (ed). CaptureBased Aquaculture. Food and Agriculture Organization of the United Nations, Rome, Italy, pp 217-253.

Walia GK, Handa D, Kaur H, Kalotra R (2013) Erythrocyte abnormalities in a freshwater fish, Labeo rohita exposed to tannery industry effluent. Int J Pharm Bio Sci 3:287-295.

Ytrestoyl T, Finstad B, McKinley RS (2001) Swimming performance and blood chemistry in Atlantic salmon spawners exposed to acid river water with elevated aluminium concentrations. J Fish Biol 58:1025-1038.

Zebral YD, Zafalon-Silva B, Mascarenhas MW, Robaldo RB (2015) Leucocyte profile and growth rates as indicators of crowding stress in pejerrey fingerlings (Odontesthes bonariensis). Aquac Res 46:2270-2276. 